\title{
48. GEOCHEMISTRY AND PETROGRAPHY OF ORGANIC MATTER FROM DEEP SEA DRILLING PROJECT SITE 603, LOWER CONTINENTAL RISE OFF CAPE HATTERAS ${ }^{1}$
}

\author{
Jürgen Rullkötter, Prasanta K. Mukhopadhyay, and Dietrich H. Welte, Institut für Erdöl and Organische \\ Geochemie, Jülich ${ }^{2}$
}

\begin{abstract}
A series of 22 sediment samples of Cretaceous and Cenozoic age from DSDP Holes 603, 603B, and 603C at the continental rise off the northeastern American coast near Cape Hatteras was investigated by organic geochemical methods including organic carbon determination, Rock-Eval pyrolysis, gas chromatography and combined gas chromatography/ mass spectrometry of extractable hydrocarbons, and kerogen microscopy. An abundance of terrigenous organic matter, including larger coal particles (almost exclusively consisting of huminite/vitrinite macerals), is the dominant characteristic of the organofacies types at Site 603. Marine organic matter, mostly structurally degraded and in the form of fecal pellets, was preserved in the Valanginian laminated marls and in Cenomanian black claystone turbidites. Long-chain $n$ alkanes reflect the terrigenous imprint in the nonaromatic hydrocarbon fractions, whereas a second maximum at lower carbon numbers in most cases is caused by the presence of more mature recycled organic matter. Abundant isoprenoid and steroid hydrocarbons were found in sediments containing mainly marine organic matter, whereas hopanoids reflect the ubiquitous microbial activity. The organic matter in the Site 603 sediments, in so far as it is not recycled, is thermally immature.
\end{abstract}

\section{INTRODUCTION}

Drilling at DSDP Site 603 (Fig. 1) was intended to penetrate a nearly complete section dating from shortly after the initial opening of the Atlantic Ocean (Jurassic) to the present. Although this target was not reached, a fairly comprehensive Cretaceous section, about $600 \mathrm{~m}$ thick and underlying about $1000 \mathrm{~m}$ of Tertiary and Holocene sediments, was recovered (Fig. 2). A number of organic-matter-rich intervals in the Cretaceous have provided valuable material for further investigation of conditions for the accumulation of organic matter in the Mesozoic North Atlantic Ocean.

DSDP Site 603 is located on the eastern North American continental margin about $400 \mathrm{~km}$ east of Cape Hatteras. Drilling was performed in the first valley of the lower continental rise hills in $4634 \mathrm{~m}$ water depth. Sediments from Holes 603, 603B, and 603C in this study are considered to represent a continuous record. This particularly refers to lithologic Unit I (0-960 m, early Pleistocene to middle Miocene) which was recovered in all three holes, whereas the other four lithologic units were only penetrated in Hole 603B.

Previous deep-sea drilling on the Hatteras continental rise was performed during DSDP Legs 11 and 44 at Sites 105, 106 (Hollister, Ewing, et al., 1972), and 388 (Benson, Sheridan, et al., 1978). At Site 105 (Fig. 1), drilling penetrated more than $600 \mathrm{~m}$ of Holocene to Jurassic sediments into basaltic basement. Organic-matter-rich intervals were recovered in the Aptian to Cenomanian in particular, and organic geochemical results

${ }^{1}$ Van Hinte, J. E., Wise, S. W., Jr., et al., Init. Repts. DSDP, 93: Washington (U.S. Govt, Printing Office).

2 Address: Institut für Erdŏl and Organische Geochemie, Kernforschungsanlage Jülich GmbH, D-5170 Jülich, Federal Republic of Germany. obtained for them by other investigators will be used for comparison with the Site 603 sediments. Drilling at Sites 106 and 388 (Fig. 1) ended in Tertiary sediments of middle Miocene and Eocene age, respectively. Organic geochemical data for these sites are scarce.

In this study, the amount, type, and composition of organic matter in the Site 603 sediments are described, and the results are discussed in terms of their origin, depositional environment, and diagenetic alteration. Comparison with the organic matter content of stratigraphically equivalent sediments will extend the present understanding of organic matter sedimentation and preservation on the eastern North American continental margin.

\section{EXPERIMENTAL METHODS}

Sediments were received frozen and were either large-size $\left(100 \mathrm{~cm}^{3}\right.$ or more) subsamples of the Organic Geochemistry Panel (OGP) core sections or small-size (a few $\mathrm{cm}^{3}$ or less) samples of hand-picked material collected on board from apparently organic-matter-rich layers.

The frozen samples were dried at $50^{\circ} \mathrm{C}$ for $12 \mathrm{hr}$. and ground. Total organic carbon (TOC) was determined with a Leco IR-112 carbon analyzer after treatment of the sediments with $25 \% \mathrm{HCl}$ to remove the carbonate carbon. Extraction was performed using a modified flowblending technique (Radke et al., 1978) with dichloromethane as the extraction solvent. the total extracts were separated into nonaromatic (saturated + olefinic) hydrocarbons, aromatic hydrocarbons, and heterocomponents by automated medium-pressure liquid chromatography (Radke et al., 1980).

A Siemens L350 gas chromatograph equipped with a $23 \mathrm{~m} \times$ $0.3 \mathrm{~mm}$ internal diameter (ID) glass capillary column coated with SE54 was used for gas chromatographic (GC) analysis of the nonaromatic hydrocarbon fractions. Helium was used as carrier gas. The temperature program was as follows: $80^{\circ} \mathrm{C}$ for $2 \min$.; 80 to $254^{\circ} \mathrm{C}$ at a rate of $3^{\circ} \mathrm{C} / \mathrm{min}$.; isothermal at $254^{\circ} \mathrm{C}$ for $25 \mathrm{~min}$.

Gas chromatography/mass spectrometry (GC/MS) was carried out on a VG $7070 \mathrm{E}$ mass spectrometer linked directly to a Carlo Erba Model 4160 gas chromatograph. Samples were injected in the splitless mode onto a $25 \mathrm{~m} \times 0.3 \mathrm{~mm}$ ID fused silica column with a chemically bound Durabond 5 stationary phase; the column was introduced di- 


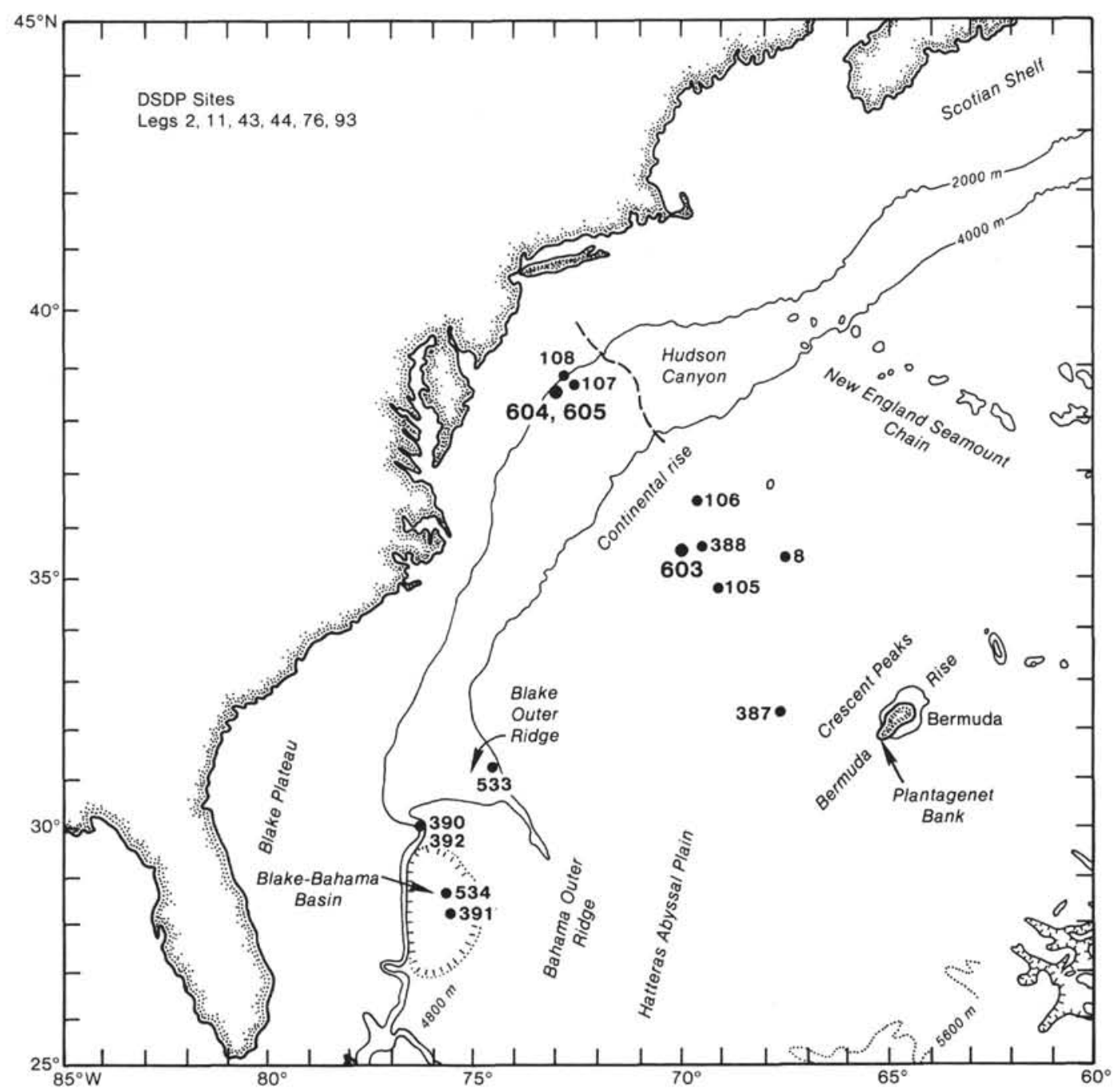

Figure 1. Location map of the northeast American continental margin showing DSDP Site 603 off Cape Hatteras and drill sites of earlier DSDP legs.

rectly into the mass spectrometer ion source. Helium was used as carrier gas, and the temperature was programmed from 70 to $300^{\circ} \mathrm{C}$ at a rate of $4^{\circ} \mathrm{C} / \mathrm{min}$. The mass spectrometer was operated at an ionization energy of $70 \mathrm{eV}$. The source temperature was kept at $220^{\circ} \mathrm{C}$, and the magnet scanned continuously at a rate of $3 \mathrm{~s} / \mathrm{scan}$. Full mass spectra were acquired, and all data were stored and processed using a DS 55 on-line data system (Kratos AEI).

Rock-Eval pyrolysis was performed according to the method described by Espitalié et al. (1977). Hydrogen and oxygen contents of the rock samples, measured as hydrocarbon-type compound and carbon dioxide yields, respectively, were normalized to organic carbon and given as hydrogen and oxygen index values for samples containing more than $0.3 \%$ TOC. Rock-Eval data of leaner samples are considered unreliable because of possible strong matrix effects. In the richer samples, Rock-Eval pyrolysis is considered a valid screening technique, although matrix effects may still occur to a certain extent.

Kerogen microscopy was restricted to samples containing more than $0.5 \%$ TOC; both separated kerogens and whole rock samples were used. Spectral fluorescence was performed only on whole rock blocks in order to avoid the effects of oxidation during kerogen separation. The separation procedure included treatment with $7.5 \mathrm{~N} \mathrm{HCl}$ followed by flotation in a high-density solution $\left(\mathrm{ZnI}_{2}, 1.9 \mathrm{~g} / \mathrm{cm}^{3}\right)$. The maceral types were analyzed using both transmitted and plane-polarized normal or fluorescene reflected light. For a description of maceral types, we refer to Stach et al. (1982) and Mukhopadhyay et al. (1985). Vitrinite reflectance (at $546 \mathrm{~nm}$ in oil) was measured on particles larger than $10 \mu \mathrm{m}$.

\section{RESULTS AND DISCUSSION}

\section{Organic Carbon}

The organic carbon contents of 22 sediment samples from DSDP Site 603 are listed in Table 1 and plotted versus depth and stratigraphic age in Figure 2. The four Tertiary sediments contain between 0.5 and $0.75 \%$ total organic carbon (TOC). This compares reasonably well with data published for DSDP Sites 388 (Erdman and Schorno, 1978; McIver and Rogers, 1978), 105, and 106 (Boyce, 1972).

In the Cretaceous section the organic matter concentrations are highly variable (Fig. 2). High values were measured in Core 603B-34 close to the Cenomanian/Turonian boundary with a maximum value of $14.5 \%$. For the same stratigraphic level in nearby DSDP Hole 105, Graciansky et al. (1982) reported organic carbon contents up to $24 \%$. Further extremely high organic carbon values in Hole 603B correspond to coaly layers in the Barremian and Berriasian-Valanginian. All these high values correspond to samples handpicked from apparently organic-matter-rich layers. Samples taken more 


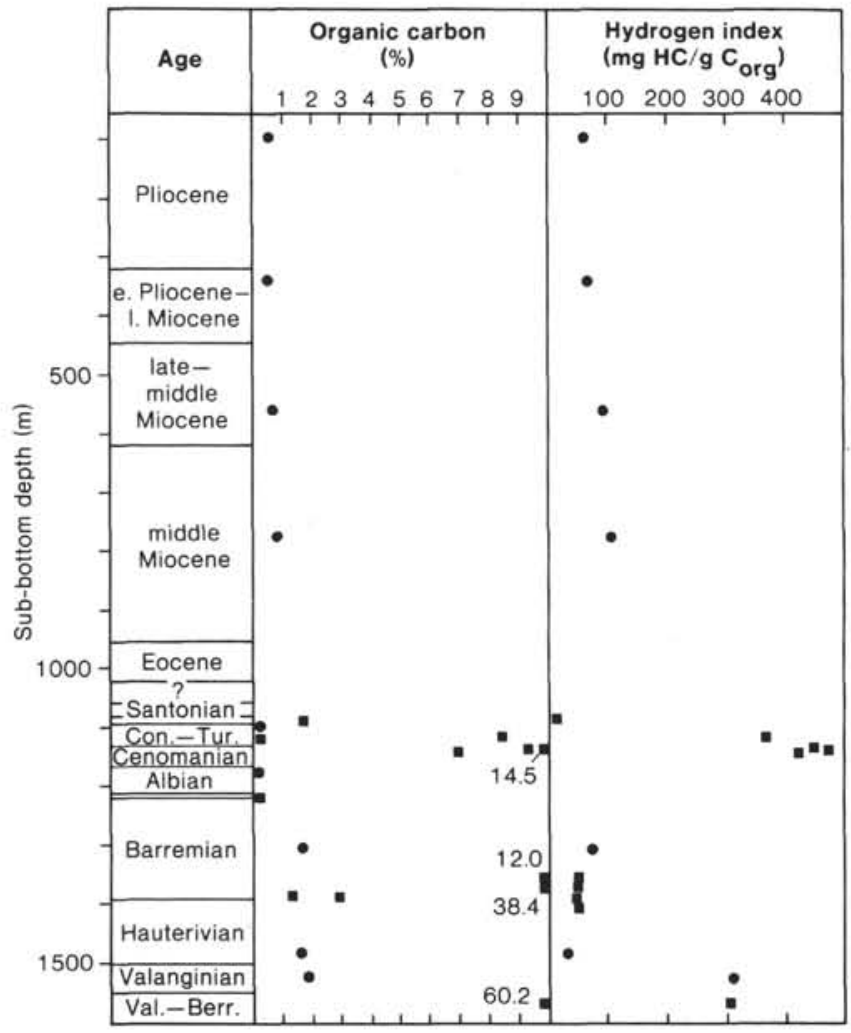

Figure 2. Organic carbon content and hydrogen index (from RockEval pyrolysis) plotted versus depth and stratigraphy for DSDP Site 603 samples. Circles represent material from Organic Geochemistry Panel (OGP) samples, squares indicate handpicked material collected on board from apparently organic-matter-rich layers. Note: There is a stratigraphically undated interval below the Santonian and a thin Aptian section below the Albian.

randomly over the penetrated interval have organic carbon contents between 1 and $2 \%$ (Valanginian to Barremian and undated sample at $1081.7 \mathrm{~m}$ ) or contain hardly any organic matter (Albian to Coniacian) (Fig. 2).

\section{Kerogen Composition by Rock-Eval Pyrolysis and Maceral Analysis}

The pyrolytic yield of hydrocarbon-type compounds, normalized to organic carbon ("Hydrogen Index"; Fig. 2 , Table 1), from the four Tertiary samples is characteristic of terrigenous organic matter that is reasonably well preserved and may even contain a small marine organic matter component. This is corroborated by the maceral composition listed in Table 2. Terrestrial humic matter (Fig. 3A) is abundant in all four samples. Liptinite macerals, which are mainly fresh pollen (sporinite) and suberinite, are the next important group, followed by inertinite particles, whereas minor amounts of dinoflagellates were observed in some of the samples (Table 2). Recycled and oxidized vitrinites having reflectance values above $0.5 \%$ mean reflectance $\left(\mathrm{R}_{\mathrm{m}}\right)$ are quite common except in Sample 603-25-4, 120-128 cm, where no evidence of recycling was noticed. The boundary between primary and recycled huminite/vitrinite particles was deduced from the sclerotinite/semifusinite reflectance (Mukhopadhyay et al., in press). This takes into account that the lowest inertinite reflectance (of sclerotin- ites or semifusinites) in a sample should be higher than the highest reflectance of primary huminites/vitrinites. Another means of distinguishing primary and recycled huminites/vitrinites is based on the observation of oxidation rims and corroded vitrinite grains that indicate recycling (Stach et al., 1982).

Sample 603B-29-1, 90-95 cm, from an undated interval just below the Santonian section, has a hydrogen index close to zero (Fig. 2) despite an organic carbon content of $1.55 \%$. About $80 \%$ of the kerogen in this sediment consists of recycled vitrinite that has lost its hydrogen content, partly during an earlier phase of burial and thermal evolution and partly by oxidation during erosion and transport to the deep sea. Remarkable in this context is the low concentration of highly inert residual organic particles in the form of inertinites in this sample and the overlying Tertiary samples. This is in contrast to other hemipelagic sediments on the continental margins of the North Atlantic, where the occurrence of inertinite in sediments deposited under oxic conditions is much more common (Rullkötter et al., 1982; Rullkötter, Mukhopadhyay, Schaefer, et al., 1984).

A great compositional similarity exists among four organic-matter-rich sediments near the Cenomanian/Turonian boundary. Three of these samples are from Core 603B-34 in the Cenomanian and one from Section 603B32-1 in the Coniacian to upper Turonian interval. The latter is from a thin, black, carbonaceous claystone interbedded in extremely organic-carbon-lean reddish brown clay (Table 1). All four show hydrogen index values around $400 \mathrm{mg} \mathrm{HC} / \mathrm{g} \mathrm{C}_{\text {org }}$ (Fig. 2), which indicates a dominance of marine (kerogen type II) organic matter. Structurally degraded (amorphous) liptinites, liptodetrinite, unicellular algae (possibly Nostocopsis), and fragments of other phytoplankton species (e.g., dinoflagellates, acritarchs) dominate in the maceral distribution (Table 2), but small amounts of fresh (translucent) spores and pollen are also common. Most of the marine liptinite in these samples occurs in oval or rounded bodies, indicating that it has reached the sediment in the form of fecal pellets. All of the degraded amorphous liptinite (sapropelinite II; Mukhopadhyay et al., 1985) in Sample 603B-34-5, 21$23 \mathrm{~cm}$ consists of fecal pellets. Abundant framboidal pyrite is commonly intermixed with the amorphous liptinite (Fig. 3B). Inertinite in the Cenomanian-Turonian sediments is relatively more abundant than in the shallower samples, whereas huminite/vitrinite particles are rare.

For a lower Turonian black shale layer $95 \mathrm{~cm}$ thick at DSDP Site 105, with organic carbon contents between 17 and $24 \%$, Herbin and Deroo (1982) measured hydrogen index values between 300 and $400 \mathrm{mg} \mathrm{HC} / \mathrm{g} \mathrm{C}_{\text {org }}$ (values very close to those determined in this study). Herbin and Deroo (1982) concluded that the organic matter essentially should be of marine origin. This is consistent with our microscopic maceral evaluation, but hydrogen index values of 300 to $400 \mathrm{mg} \mathrm{HC} / \mathrm{g} \mathrm{C}_{\text {org }}$ still are fairly low for typical immature aquatic organic matter. The explanation is probably given by the detection of fecal pellets as the dominant organic particles in the sediment, indicating that most of the lipid material contained in the fecal pellets has undergone metabolic alter- 
Table 1. Lithology, stratigraphy, organic carbon content, and Rock-Eval pyrolysis data.

\begin{tabular}{|c|c|c|c|c|c|c|c|c|c|}
\hline \multirow[b]{2}{*}{$\begin{array}{l}\text { Core-Section } \\
\text { (interval in } \mathrm{cm} \text { ) }\end{array}$} & \multirow[b]{2}{*}{ Subunit } & \multirow[b]{2}{*}{$\begin{array}{l}\text { Depth } \\
\text { (m) }\end{array}$} & \multirow[b]{2}{*}{ Lithology } & \multirow[b]{2}{*}{$\begin{array}{l}\text { Stratigraphic } \\
\text { age }\end{array}$} & \multirow{2}{*}{$\begin{array}{c}\text { Organic } \\
\text { carbon } \\
(\%)\end{array}$} & \multicolumn{4}{|c|}{ Rock-Eval pyrolysis } \\
\hline & & & & & & $\begin{array}{l}\text { Hydrogen index } \\
\left(\mathrm{mg} \mathrm{HC} / \mathrm{g} \mathrm{C}_{\text {org }}\right)\end{array}$ & $\begin{array}{c}\text { Oxygen index } \\
\left(\mathrm{mg} \mathrm{CO}_{2} / \mathrm{g} \mathrm{C}_{\text {org }}\right)\end{array}$ & $\begin{array}{l}\text { Production } \\
\text { index }\end{array}$ & $T_{\max }\left({ }^{\circ} \mathrm{C}\right)$ \\
\hline \multicolumn{10}{|l|}{ Hole $603 \mathrm{C}$} \\
\hline $11-3,141-150$ & IA & 89.2 & $\begin{array}{l}\text { Bioturb. greenish } \\
\text { gray claystone }\end{array}$ & Pliocene & 0.52 & 71 & 464 & 0.28 & 381 \\
\hline $37-5,141-150$ & IA & 335.0 & $\begin{array}{l}\text { Bioturb. greenish } \\
\text { gray claystone }\end{array}$ & $\begin{array}{l}\text { early Pliocene- } \\
\text { late Miocene }\end{array}$ & 0.53 & 74 & 318 & 0.23 & 407 \\
\hline \multicolumn{10}{|l|}{ Hole 603} \\
\hline $25-4,120-128$ & IB & 550.5 & $\begin{array}{c}\text { Greenish gray } \\
\text { sandy clay } \\
\text { (friable) }\end{array}$ & $\begin{array}{l}\text { middle-late } \\
\text { Miocene }\end{array}$ & 0.63 & 99 & 310 & 0.19 & 405 \\
\hline $49-2,120-128$ & IB & 768.3 & $\begin{array}{c}\text { Greenish gray } \\
\text { claystone }\end{array}$ & middle Miocene & 0.75 & 114 & 206 & 0.16 & 418 \\
\hline \multicolumn{10}{|l|}{ Hole 603B } \\
\hline $29-1,90-95$ & IIIB & 1081.7 & $\begin{array}{l}\text { Gray sandy clay- } \\
\text { stone with mica }\end{array}$ & $?$ & 1.55 & 18 & 7 & 0.08 & 426 \\
\hline $29-3,123-127$ & IIIC & 1086.0 & $\begin{array}{l}\text { Reddish brown } \\
\text { claystone } \\
\text { (friable) }\end{array}$ & $?$ & 0.07 & & & & \\
\hline $32-1,21-23$ & IIIC & 1109.7 & $\begin{array}{l}\text { Reddish brown } \\
\text { clay (limonitic) }\end{array}$ & $\begin{array}{l}\text { Coniacian to } \\
\text { late Turonian }\end{array}$ & 0.14 & & & & \\
\hline $32-1,26-28$ & IIIC & 1109.8 & $\begin{array}{l}\text { Dark gray clay- } \\
\text { stone with sandy } \\
\text { stringers }\end{array}$ & $\begin{array}{l}\text { Coniacian to } \\
\text { late Turonian }\end{array}$ & 8.48 & 346 & 11 & 0.01 & 417 \\
\hline $32-1,30-32$ & IIIC & 1109.8 & $\begin{array}{l}\text { Mottled clayey } \\
\text { sandstone }\end{array}$ & $\begin{array}{l}\text { Coniacian to } \\
\text { late Turonian }\end{array}$ & 0.14 & & & & \\
\hline $34-1,77-79$ & IVA & 1128.2 & Black claystone & Cenomanian & 9.32 & 474 & 5 & 0.02 & 413 \\
\hline $34-3,68-70$ & IVA & 1132.6 & Black claystone & Cenomanian & 14.5 & 447 & 11 & 0.03 & 406 \\
\hline $34-5,21-23$ & IVA & 1135.2 & Black claystone & Cenomanian & 6.76 & 419 & 7 & 0.06 & 413 \\
\hline $38-3,135-138$ & IVB & 1168.0 & $\begin{array}{l}\text { Red sandy } \\
\text { claystone }\end{array}$ & Albian & 0.05 & & & & \\
\hline $43-4,5-10$ & IVC & 1210.5 & $\begin{array}{l}\text { Reddish brown } \\
\text { sandy claystone }\end{array}$ & Aptian & 0.03 & & & & \\
\hline $53-4,132-135$ & VA & 1300.6 & $\begin{array}{l}\text { Light gray } \\
\text { sandy claystone }\end{array}$ & late Barremian & 1.38 & 75 & 93 & 0.04 & 425 \\
\hline $58-1,79-80$ & VA & 1349.6 & $\begin{array}{l}\text { Gray sandy } \\
\text { claystone with } \\
\text { vitrain (coaly } \\
\text { fragment) }\end{array}$ & early Barremian & 12.0 & 42 & 43 & 0.03 & 421 \\
\hline $58-1,114-115$ & VA & 1349.9 & $\begin{array}{l}\text { Gray sandy } \\
\text { claystone with } \\
\text { coaly fragments }\end{array}$ & early Barremian & 38.4 & 55 & 24 & 0.02 & 425 \\
\hline $60-3,112-113$ & VA & 1373.6 & $\begin{array}{l}\text { Gray calcareous } \\
\text { sandstone with } \\
\text { coaly fragments }\end{array}$ & early Barremian & 1.13 & 54 & 58 & 0.02 & 425 \\
\hline $61-5,41-42$ & VA & 1385.5 & $\begin{array}{l}\text { Gray calcareous } \\
\text { and sandy clay- } \\
\text { stone with coaly } \\
\text { fragments }\end{array}$ & early Barremian & 2.81 & 47 & 47 & 0.03 & 421 \\
\hline $71-5,130-135$ & VA & 1477.5 & $\begin{array}{l}\text { Greenish gray } \\
\text { micaceous sandy } \\
\text { claystone }\end{array}$ & late Hauterivian & 1.35 & 36 & 70 & 0.06 & 422 \\
\hline $76-3,130-135$ & VB & 1517.3 & $\begin{array}{l}\text { Lamin. ash gray } \\
\text { sandy and marly } \\
\text { claystone }\end{array}$ & Valanginian & 1.63 & 311 & 60 & 0.01 & 425 \\
\hline $80-6,48$ & VB & 1557.2 & $\begin{array}{l}\text { Black coaly } \\
\text { fragment }\end{array}$ & $\begin{array}{l}\text { Berriasian to } \\
\text { Valanginian }\end{array}$ & 60.2 & 304 & 10 & 0.02 & 404 \\
\hline
\end{tabular}

ation and may have lost a certain proportion of its initial hydrogen content.

The upper Hauterivian to upper Barremian sediments are rich in huminites and vitrinites of terrigenous origin. They are either primary ("autochthonous"; Fig. 3C) or a mixture of primary and recycled ("allochthonous"; Fig. 3D) particles. The huminites mainly belong to the eu-ulminite and gelinite subgroups, whereas textinite was not observed. Most of the ulminite and gelinite particles contain layers of framboidal pyrite (e.g., in Sample 603B-
58-1, 79-80 cm; Figs. 3C and 3D). In general, the upper Hauterivian to upper Barremian samples contain less than $20 \%$ liptinite, which consists of terrigenous spores and pollen. The Hauterivian sample (603B-71-5, 130$135 \mathrm{~cm}$ ) contains a very high proportion of recycled vitrinites with reflectance values beyond $1 \% \mathrm{R}_{\mathrm{m}}$.

Hydrogen index values between 36 and $75 \mathrm{mg} \mathrm{HC} / \mathrm{g}$ $\mathrm{C}_{\text {org }}$ reflect the terrigenous higher plant origin of the organic matter in the Hauterivian to Barremian sediments. This is true irrespective of the wide range of organic car- 
Table 2. Vitrinite reflectance, thermal alteration index and maceral composition data.

\begin{tabular}{|c|c|c|c|c|c|c|c|c|c|c|c|c|c|c|}
\hline \multirow{3}{*}{$\begin{array}{l}\text { Core-Section } \\
\text { (interval in cm) }\end{array}$} & \multirow{3}{*}{$\begin{array}{l}\text { Depth } \\
\text { (m) }\end{array}$} & \multirow{3}{*}{$\begin{array}{l}\text { Stratigraphic } \\
\text { age }\end{array}$} & \multirow{2}{*}{\multicolumn{2}{|c|}{ Vitrinite reflectance }} & \multirow{3}{*}{$\begin{array}{c}\text { Thermal } \\
\text { alteration } \\
\text { index (after } \\
\text { Staplin, 1969) }\end{array}$} & \multicolumn{9}{|c|}{ Maceral composition (vol. \%) } \\
\hline & & & & & & \multicolumn{2}{|c|}{1} & \multirow[b]{2}{*}{2} & \multirow[b]{2}{*}{3} & \multirow[b]{2}{*}{4} & \multirow[b]{2}{*}{5} & \multirow[b]{2}{*}{6} & \multirow[b]{2}{*}{7} & \multirow[b]{2}{*}{8} \\
\hline & & & $R_{\mathrm{m}}$ & Std. Dev. & & A & B & & & & & & & \\
\hline \multicolumn{15}{|l|}{ Hole $603 \mathrm{C}$} \\
\hline $11-3,141-150$ & 89.2 & Pliocene & 0.19 & 0.05 & $1^{-}$ & 34 & 44 & 2 & 6 & 10 & 2 & 1 & 1 & Absent \\
\hline $37-5,141-150$ & 335.0 & $\begin{array}{l}\text { early Pliocene- } \\
\text { late Miocene }\end{array}$ & 0.23 & 0.06 & $1^{-}$ & 36 & 38 & & 16 & 8 & 1 & 1 & & Absent \\
\hline \multicolumn{15}{|l|}{ Hole 603} \\
\hline $25-4,120-128$ & 550.5 & $\begin{array}{l}\text { middle- } \\
\text { late Miocene }\end{array}$ & 0.34 & 0.03 & $1^{-}$ & 90 & 5 & & 2 & 3 & & & & Absent \\
\hline $49-2,120-128$ & 768.3 & $\begin{array}{l}\text { middle } \\
\text { Miocene }\end{array}$ & 0.26 & 0.05 & $1^{-}$ & 26 & 46 & & 7 & 19 & 2 & & & Absent \\
\hline \multicolumn{15}{|l|}{ Hole 603B } \\
\hline $29-1,90-95$ & 1081.7 & ? & 0.29 & 0.06 & $1^{-}$ & 10 & 78 & & 11 & 1 & & & & Absent \\
\hline $32-1,26-28$ & 1109.8 & $\begin{array}{l}\text { Coniacian to } \\
\text { late Turonian }\end{array}$ & 0.25 & 0.07 & $1^{-}$ & 4 & 2 & 13 & 1 & 7 & 9 & 56 & 5 & Present \\
\hline $34-1,77-79$ & 1128.2 & Cenomanian & 0.28 & 0.03 & $1^{-}$ & 2 & 2 & 6 & 1 & 10 & 30 & 40 & 7 & Abundant \\
\hline $34-3,68-70$ & 1132.6 & Cenomanian & 0.31 & 0.03 & $1^{-}$ & 2 & 3 & 10 & 1 & 8 & 24 & 48 & 4 & Abundant \\
\hline $34-5,21-23$ & 1135.2 & Cenomanian & 0.28 & 0.08 & $1^{-}$ & 2 & 2 & 12 & 1 & 7 & 22 & 50 & 4 & Abundant \\
\hline $53-4,132-135$ & 1300.6 & late Barremian & 0.26 & 0.06 & $1^{-}$to $1^{+}$ & 36 & 39 & 3 & 5 & 13 & 3 & 1 & & Rare \\
\hline $58-1,79-80$ & 1349.6 & early Barremian & 0.37 & 0.03 & $1^{-}$to $1^{+}$ & 72 & 18 & 2 & 1 & 5 & 2 & & & $\begin{array}{l}\text { Abundant } \\
\text { parallel to } \\
\text { bedding }\end{array}$ \\
\hline $58-1,114-115$ & 1349.9 & early Barremian & 0.30 & 0.02 & - & 95 & 2 & & 1 & 2 & & & & $\begin{array}{l}\text { Same as } \\
\text { above }\end{array}$ \\
\hline $60-3,112-113$ & 1373.6 & early Barremian & 0.36 & 0.04 & $1^{-}$to $1^{+}$ & 82 & 12 & & 4 & 2 & & & & $\begin{array}{l}\text { Same as } \\
\text { above }\end{array}$ \\
\hline $61-5,41-42$ & 1385.5 & early Barremian & 0.35 & 0.08 & $1^{-}$to $1^{+}$ & 77 & 10 & & 11 & 2 & & & & $\begin{array}{l}\text { Same as } \\
\text { above }\end{array}$ \\
\hline $71-5,130-135$ & 1477.5 & late Hauterivian & 0.31 & 0.08 & $1^{-}$to $1^{+}$ & 25 & 73 & & 1 & 1 & & & & Rare \\
\hline $76-3,130-135$ & 1517.3 & Valanginian & 0.29 & 0.06 & $1^{-}$to $1^{+}$ & 4 & 4 & 3 & 10 & 20 & 12 & 45 & 2 & Abundant \\
\hline $80-6,48$ & 1557.2 & $\begin{array}{l}\text { Berriasian - } \\
\text { Valanginian }\end{array}$ & $0.24^{\mathrm{a}}$ & 0.03 & $1^{-}$to $1^{+}$ & 96 & & & 2 & 2 & & & & Abundant \\
\hline
\end{tabular}

Note: 1A: autochthonous huminite (terrigenous); 1B: allochthonous huminite/vitrinite (terrigenous); 2: mixed amorphous humic and liptinite matter (humosapropelinite) (mostly terrigenous); 3: inertinite (mostly terrigenous); 4: sporinite, cutinite, suberinite, resinite (terrigenous); 5: phyto- and zooplankton (marine); 6: biodegradated liptinite (sapropelinite II) (mostly marine); 7: alginite (marine); 8: pyrite content.

${ }^{a}$ Vitrinites are highly bitumen-impregnated.

bon values between 1.13 and $38.4 \%$. The organic material found in this stratigraphic interval apparently consists of coal that initially was deposited in a nearby coastal swamp, as indicated by the presence of pyrite associated with the coaly particles. Sulfate concentrations in freshwater swamps are too low to be responsible for the amount of pyrite found in the Hole 603B samples, and the good preservation of both the huminites and the pyrite precludes long-distance transport. The coal particles were mixed with the lithogenic material in the turbidites, and the different degrees of dilution as well as sampling bias explain the variation in organic carbon contents.

Both the samples from the Valanginian and the Valanginian-Berriasian sections show high hydrogen index values despite their enormous difference in organic carbon content (1.6 vs. $60 \% \mathrm{C}_{\text {org }}$; Fig. 2$)$. The shallower sample (603B-76-3, 130-135 cm) is from a laminated, organic-matter- and nannofossil-bearing claystone with interbedded limestone, whereas Sample 603B-80-6, $48 \mathrm{~cm}$ is handpicked from an organic-matter- and plant-debrisbearing limestone/chalk in which the organic matter is concentrated in varvelike laminations. Despite the similarity in pyrolysis yields, the maceral compositions are totally different. The Valanginian sample contains a mixture of marine and terrigenous organic matter represented by dinoflagellates, and spores and pollen, respectively. An abundant portion of these lipid-rich macerals apparently is structurally degraded (so-called sapropelinite II), often impregnated with bitumen and framboidal pyrite, and has reached the sediment as fecal pellets (Fig. 3E). In contrast, the Valanginian-Berriasian sample contains coaly material (gelinite and ulminite), which is highly impregnated with bitumen. The main huminite macerals (Fig. 3F) have a much lower reflectance than the subordinate ulminite. They have a reddish brown to brown fluorescence with positive alteration. Pyrite is abundant and mostly occurs parallel to the bedding of maceral stratification. The nature of the huminite macerals suggests that they were deposited in a sapropelic environment and thus are called saprohuminites. This type of maceral is rare and particularly uncommon in deep-sea sediments. Since only a very small piece of the coaly material of Valanginian-Berriasian age was obtained for investigation, it is not clear at the moment if there is any relationship to the Valanginian sediment containing a high proportion of marine organic matter. Because both samples are from the same litho- 

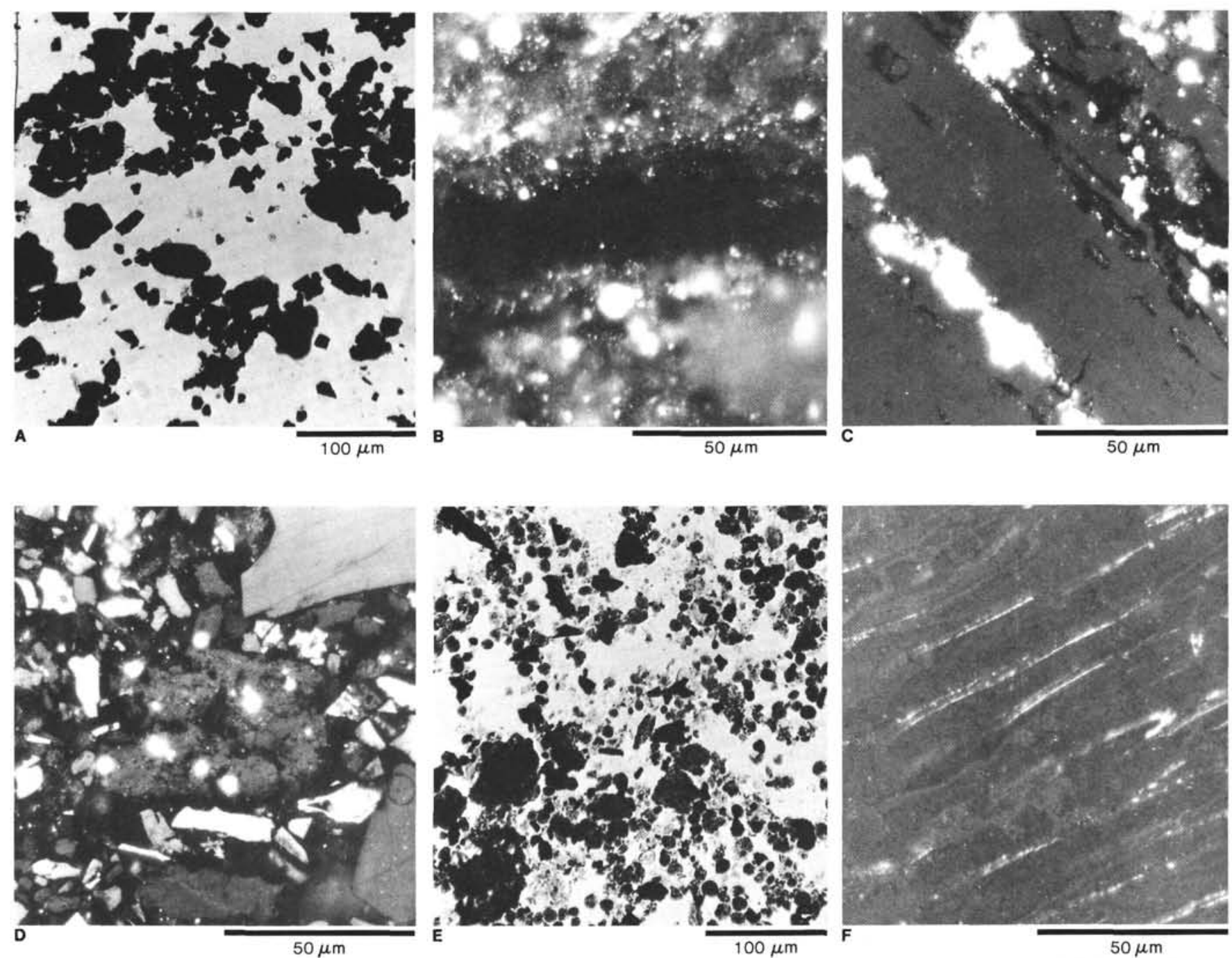

Figure 3. Kerogen microphotographs of DSDP Site 603 samples. A. Sample 603B-29-1, 90-95 cm: Humic matter (huminite/vitrinite, mostly recycled) and charcoal. Kerogen smear slide in transmitted white light. B. Sample 603B-34-1, 77-79 cm: Amorphous liptinite (sapropelinite II: dark band in the middle) and framboidal pyrite. Polished whole rock block in reflected white light. C. Sample 603B-58-1, 79-80 cm: Gelinite (huminite) with framboidal pyrite. Polished whole rock block in reflected white light. D. Sample 603B-53-4, 132-135 cm: Ulminite, gelinite, recycled telocollinite of varying reflectance, and inertodetrinite. Polished kerogen concentrate in reflected white light. E. Sample 603B-76-3, 130-135 cm: Dinoflagellates, biodegraded liptinite (sapropelinite II, partly as fecal pellets), trilete/monosaccate spores and humic matter (huminite/vitrinite). Kerogen smear slide in transmitted white light. F. Sample 603B-80-6, $48 \mathrm{~cm}$ : Saprohuminite, ulminite (minor), and pyrite. Polished whole rock block in reflected white light.

logic unit, it seems possible that the huminite-rich material was embedded in a layer of lipid-rich organic matter that may be responsible for the bitumen impregnation of the huminites.

Herbin and Deroo (1982) reported hydrogen index values up to $330 \mathrm{mg} \mathrm{HC} / \mathrm{g} \mathrm{C}_{\text {org }}$ for laminated marls from the Blake-Bahama Formation of the North American continental margin, without further specifying the wells the sediments were obtained from and their stratigraphic age. The laminated marls may, however, be an equivalent of the lithologic Unit VB sediments of DSDP Hole 603B. A single sample containing mainly amorphous organic matter, possibly of aquatic origin, was described by Summerhayes (1981) for the Neocomian section at Site 105, although the dominant organofacies was found to be terrigenous in this interval.

\section{Extractable Hydrocarbons}

Total extract yields varying between 15 and $20 \mathrm{mg} / \mathrm{g}$ $\mathrm{C}_{\text {org }}$ in the DSDP Site 603 sediments are typical of immature organic matter in the early diagenetic stage (Rullkötter et al., 1981). Values up to $30 \mathrm{mg} / \mathrm{g} \mathrm{C}_{\text {org }}$ were obtained for the liptinite-rich sediments of Cenomanian and Valanginian age. Even higher values in Table 3 are artifacts of normalization of low absolute extract yields from extremely organic-carbon-lean sediments. Extract yields below $15 \mathrm{mg} / \mathrm{g} \mathrm{C}_{\text {org }}$ represent samples that contain an abundance of humic terrigenous organic matter or inert recycled material.

Polar components form the bulk of the extract when it is separated by liquid chromatography. This is what can be expected for immature organic matter. Again, 
Table 3. Extract and liquid chromatography yields.

\begin{tabular}{|c|c|c|c|c|c|c|c|c|}
\hline \multirow[b]{2}{*}{$\begin{array}{l}\text { Core-Section } \\
\text { (interval in } \mathrm{cm} \text { ) }\end{array}$} & \multirow[b]{2}{*}{$\begin{array}{l}\text { Depth } \\
\text { (m) }\end{array}$} & \multirow[b]{2}{*}{$\begin{array}{l}\text { Stratigraphic } \\
\text { age }\end{array}$} & \multirow{2}{*}{\multicolumn{2}{|c|}{$\begin{array}{c}\text { Total extract } \\
(\mathrm{ppm}) \quad\left(\mathrm{mg} / \mathrm{g} \mathrm{C}_{\text {org }}\right)\end{array}$}} & \multicolumn{3}{|c|}{ Hydrocarbons } & \multirow{2}{*}{$\begin{array}{l}\text { Heterocomponents } \\
+ \text { residue } \\
(\%)\end{array}$} \\
\hline & & & & & $\begin{array}{c}\text { Total } \\
\text { (mg/g C }\end{array}$ & $\begin{array}{c}\text { Nonaromatic } \\
(\%)\end{array}$ & $\begin{array}{c}\text { Aromatic } \\
(\%)\end{array}$ & \\
\hline \multicolumn{9}{|l|}{ Hole $603 \mathrm{C}$} \\
\hline $11-3,141-150$ & 89.2 & Pliocene & 98 & 98 & 2.3 & 13.3 & 2.2 & 84.5 \\
\hline $37-5,141-150$ & 335.0 & $\begin{array}{l}\text { early Pliocene- } \\
\text { late Miocene }\end{array}$ & 94 & 18 & 3.0 & 19.0 & 3.4 & 77.6 \\
\hline \multicolumn{9}{|l|}{ Hole 603} \\
\hline $25-4,120-128$ & 550.5 & $\begin{array}{l}\text { middle- } \\
\text { late Miocene }\end{array}$ & 100 & 16 & 1.8 & 13.9 & 3.8 & 82.3 \\
\hline $49-2,120-128$ & 768.3 & middle Miocene & 113 & 15 & 1.7 & 14.0 & 1.6 & 84.4 \\
\hline \multicolumn{9}{|l|}{ Hole 603B } \\
\hline $29-1,90-95$ & 1081.7 & ? & 42 & 3 & 0.7 & 27.3 & 13.6 & 59.1 \\
\hline $29-3,123-127$ & 1086.0 & $?$ & 30 & 43 & 11.4 & 30.8 & 23.1 & 46.1 \\
\hline $32-1,21-23$ & 1109.7 & $\begin{array}{l}\text { Coniacian to late } \\
\text { Turonian }\end{array}$ & 27 & 19 & 4.8 & 28.6 & 28.6 & 43.8 \\
\hline $32-1,26-28$ & 1109.8 & $\begin{array}{l}\text { Coniacian to late } \\
\text { Turonian }\end{array}$ & 1309 & 15 & 1.4 & 10.7 & 6.6 & 82.7 \\
\hline $32-1,30-32$ & 1109.8 & $\begin{array}{c}\text { Coniacian to late } \\
\text { Turonian }\end{array}$ & 60 & 43 & 14.3 & 36.4 & 27.3 & 36.3 \\
\hline $34-1,77-79$ & 1128.2 & Cenomanian & 2350 & 25 & 0.8 & 3.4 & 3.4 & 93.2 \\
\hline $34-3,68-70$ & 1132.6 & Cenomanian & 4350 & 30 & 1.3 & 5.3 & 4.2 & 90.5 \\
\hline $34-5,21-23$ & 1135.2 & Cenomanian & 1520 & 22 & 0.8 & 4.6 & 3.8 & 90.6 \\
\hline $38-3,135-138$ & 1168.0 & Albian & 36 & 72 & 32.0 & 50.0 & 18.8 & 31.2 \\
\hline $43-4,5-10$ & 1210.9 & Aptian & 15 & 50 & 17.7 & 33.3 & 33.3 & 33.4 \\
\hline $53-4,132-135$ & 1300.6 & late Barremain & 153 & 11 & 1.9 & 20.5 & 15.4 & 64.1 \\
\hline $58-1,79-80$ & 1349.6 & early Barremain & 240 & 2 & 0.1 & 4.5 & 13.6 & 81.9 \\
\hline $60-3,112-113$ & 1373.6 & early Barremian & 67 & 6 & 1.0 & 18.2 & 9.1 & 72.7 \\
\hline $61-5,41-42$ & 1385.5 & early Barremian & 130 & 5 & 0.7 & 16.7 & 25.0 & 58.3 \\
\hline $71-5,130-135$ & 1477.5 & late Hauterivian & 107 & 8 & 0.8 & 11.1 & 3.7 & 85.2 \\
\hline $76-3,130-135$ & 1517.3 & Valanginian & 402 & 25 & 1.3 & 8.3 & 6.7 & 85.0 \\
\hline
\end{tabular}

the values for the extremely organic-carbon-lean samples in Table 3 are not considered to be accurate and should be disregarded. The relative proportion of hydrocarbons is lowest in the sediments containing mainly (aquatic) liptinite material (the Cenomanian and Valanginian samples). The ratio of nonaromatic to aromatic hydrocarbons is close to unity in these samples, whereas the nonaromatic hydrocarbons clearly dominate over the aromatic hydrocarbons in the sediment with mainly huminite/vitrinite macerals of terrigenous origin, probably caused by an abundance of higher plant wax alkanes.

Capillary column gas chromatograms of the nonaromatic hydrocarbon fractions of 10 selected samples from DSDP Site 603 are shown in Figure 4. Compounds identified by GC/MS based on relative retention times and mass spectral interpretations are marked in the chromatograms and listed in Table 4. Sample 603-49-2, 120$128 \mathrm{~cm}$ (middle Miocene) contains abundant long-chain $n$-alkanes with a maximum at $n$ - $\mathrm{C}_{29}$ and a strong oddover-even carbon number predominance (Fig. 4A). This is consistent with the presence of mainly terrigenous organic matter in this sample. Hopanoid hydrocarbons are derived from the bacterial biomass (Ourisson et al., 1979) incorporated into the sediment, and unsaturated steroid hydrocarbons indicate that there is a marine component and at the same time a good preservation of the organic matter in this sample because steroids are very sensitive to oxidation (Gagosian et al., 1982).
A bimodal $n$-alkane distribution is shown in Figure 4B for Sample 603B-29-1, 90-95 cm, from $1081.7 \mathrm{~m}$ sub-bottom depth, within an undated interval. The longchain $n$-alkanes around $n-C_{29}$ reflect the presence of unaltered humic material, whereas the shorter-chain $n$-alkanes with a maximum at $n-\mathrm{C}_{19}$ are ascribed to more mature organic matter that corresponds to the $80 \%$ reworked vitrinites in this sample with a considerably higher reflectance than the primary huminites. Steroid hydrocarbons are absent, but small amounts of hopanoid hydrocarbons reflect the ubiquitous activity of microorganisms in sediments (Ourisson et al., 1979).

The capillary column gas chromatograms of the four organic-matter-rich sediments of Coniacian-Turonian and Cenomanian age are shown in Figures 4C-F. Although Rock-Eval pyrolysis yields and maceral composition indicated a very similar organic matter type for all four samples, the nonaromatic hydrocarbon distributions exhibit some major differences. In Sample 603B$32-1,26-28 \mathrm{~cm}$, the $n$-alkanes are abundant and are dominant over the branched and cyclic hydrocarbons, although the relative $n$-alkane distribution is not much different from those of the three Cenomanian samples (even if this is hard to visualize in the chromatograms because of different normalization). Since not much reworked organic matter has been observed microscopically, the short-chain $n$-alkanes around $n$ - $\mathrm{C}_{17}$ in Figure $4 \mathrm{C}$ and likewise in the Cenomanian samples are probably derived from the marine organic matter in these sed- 

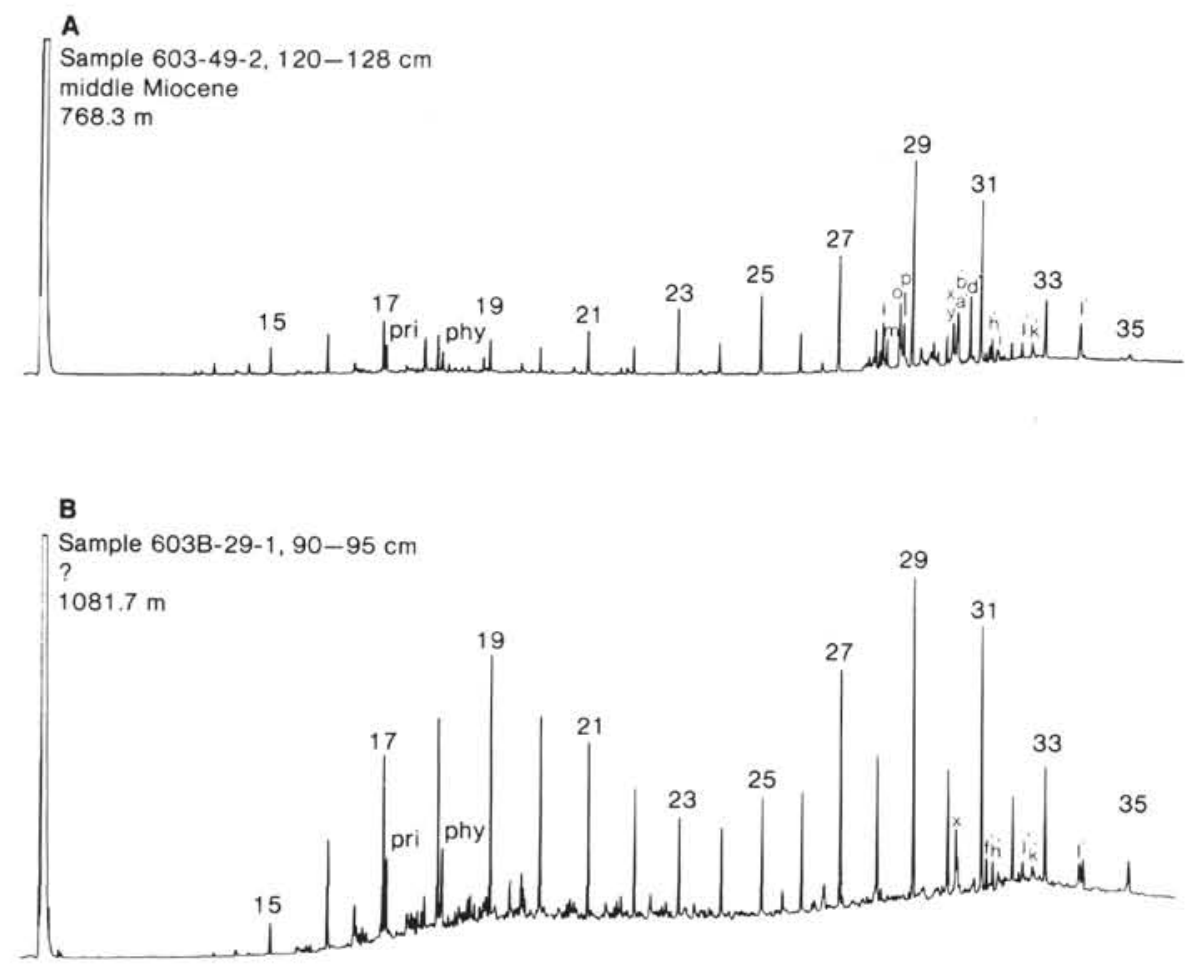

C

Sample 603B-32-1, 26-28 cm

Coniacian-late Turonian

$1109.8 \mathrm{~m}$

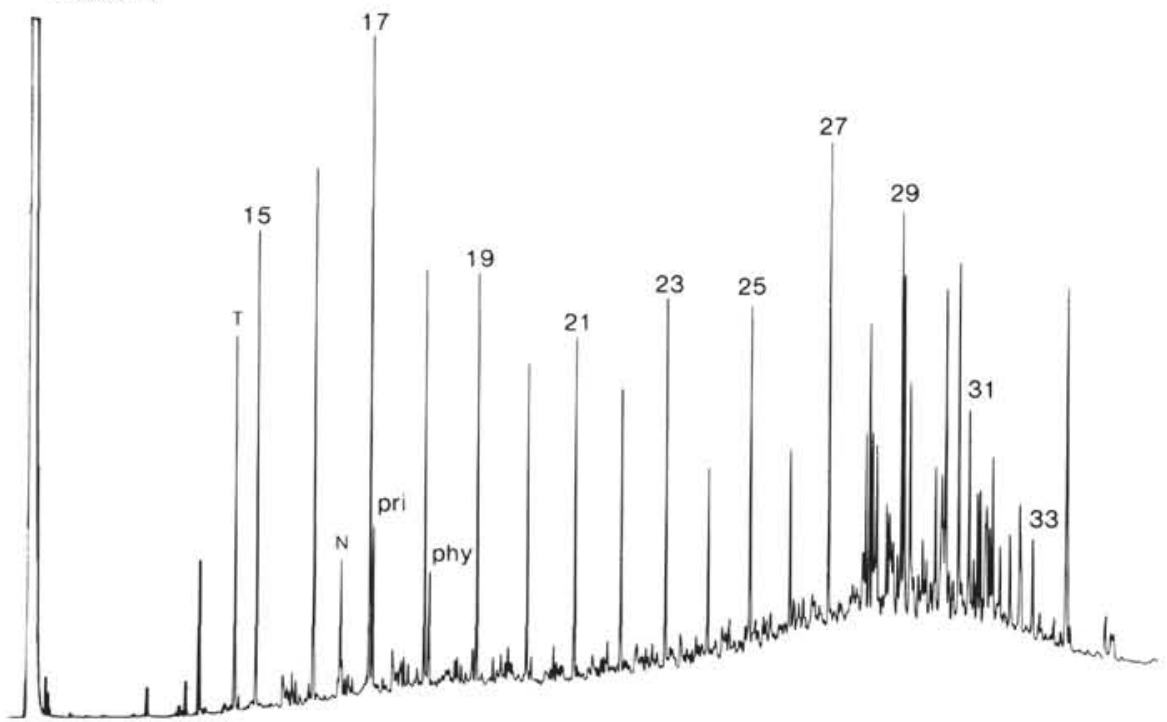

Figure 4. Capillary column gas chromatograms of the nonaromatic hydrocarbon fractions separated from the total extract of ten selected sediment samples from DSDP Site 603. n-Alkanes are marked by their carbon numbers. For lettered compounds see Table 4 .

iments. The Cenomanian sample from Section 603B34-3 has an unusual abundance of long-chain $n$-alkanes ranging from $\mathrm{C}_{31}$ to at least $\mathrm{C}_{37}$ without any significant odd-over-even predominance (Fig. 4E). These are certainly not from terrestrial higher plant waxes but are most likely from coccolithophores that are known to contain long-chain ketones and alkenes with 37 and 38 carbon atoms (Leeuw et al., 1980; Volkman et al., 1980). These long-chain $n$-alkanes were not found in the other two Cenomanian samples (603B-34-1, 77-79 $\mathrm{cm}$ and 603B-34-5, 21-23 cm) and the Coniacian-Turonian sediment (Figs. 4C, 4D, and 4F).

The branched and cyclic nonaromatic hydrocarbon composition of two of the Cenomanian samples is nearly identical (Figs. 4D and 4F). It differs significantly from that of the third Cenomanian sample (Fig. 4E) but less so from that of the Coniacian-Turonian sediment (Fig. 4C). Pristane and phytane are fairly abundant rela- 

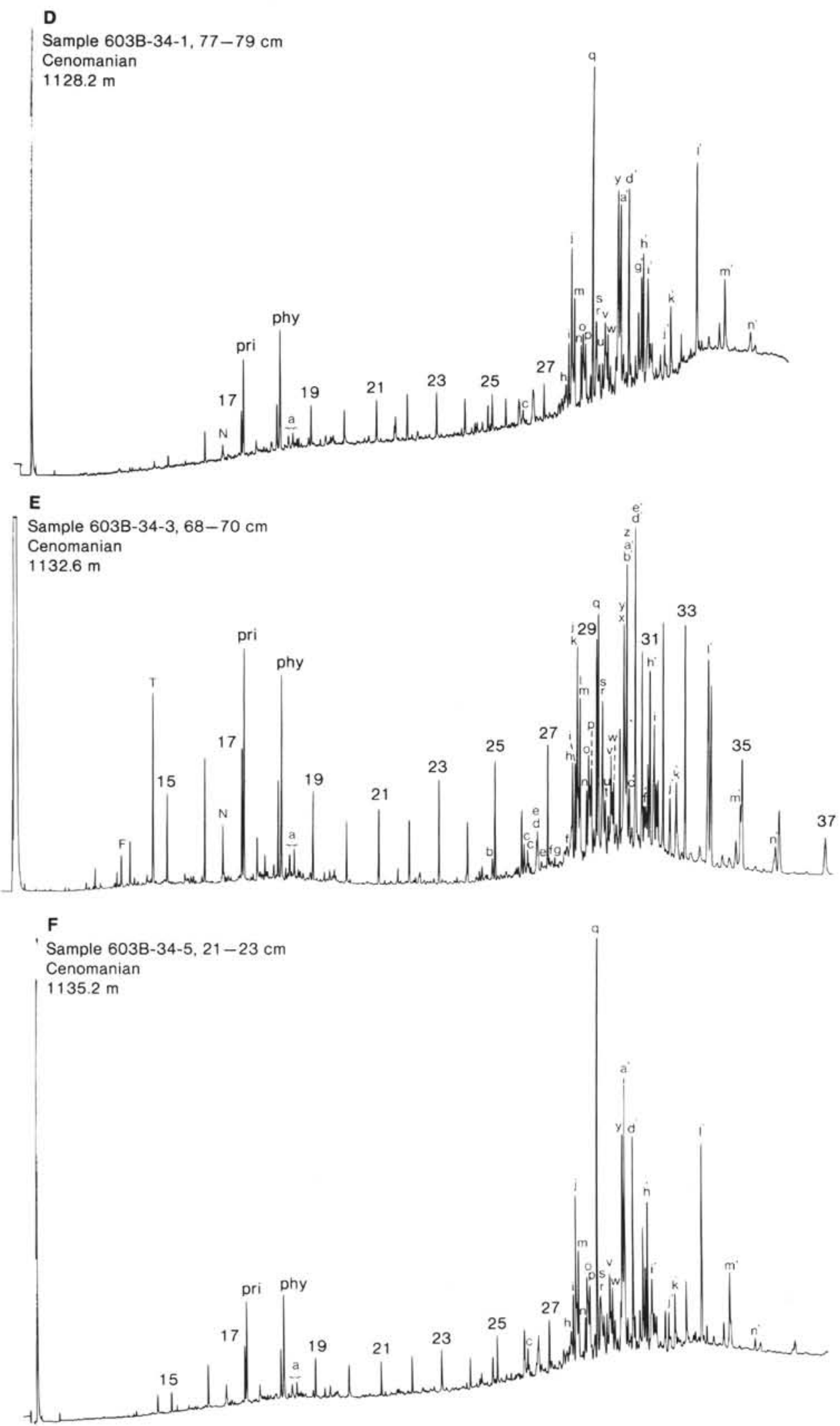

Figure 4 (continued). 
J. RULLKÖTTER, P. K. MUKHOPADHYAY, D. H. WELTE

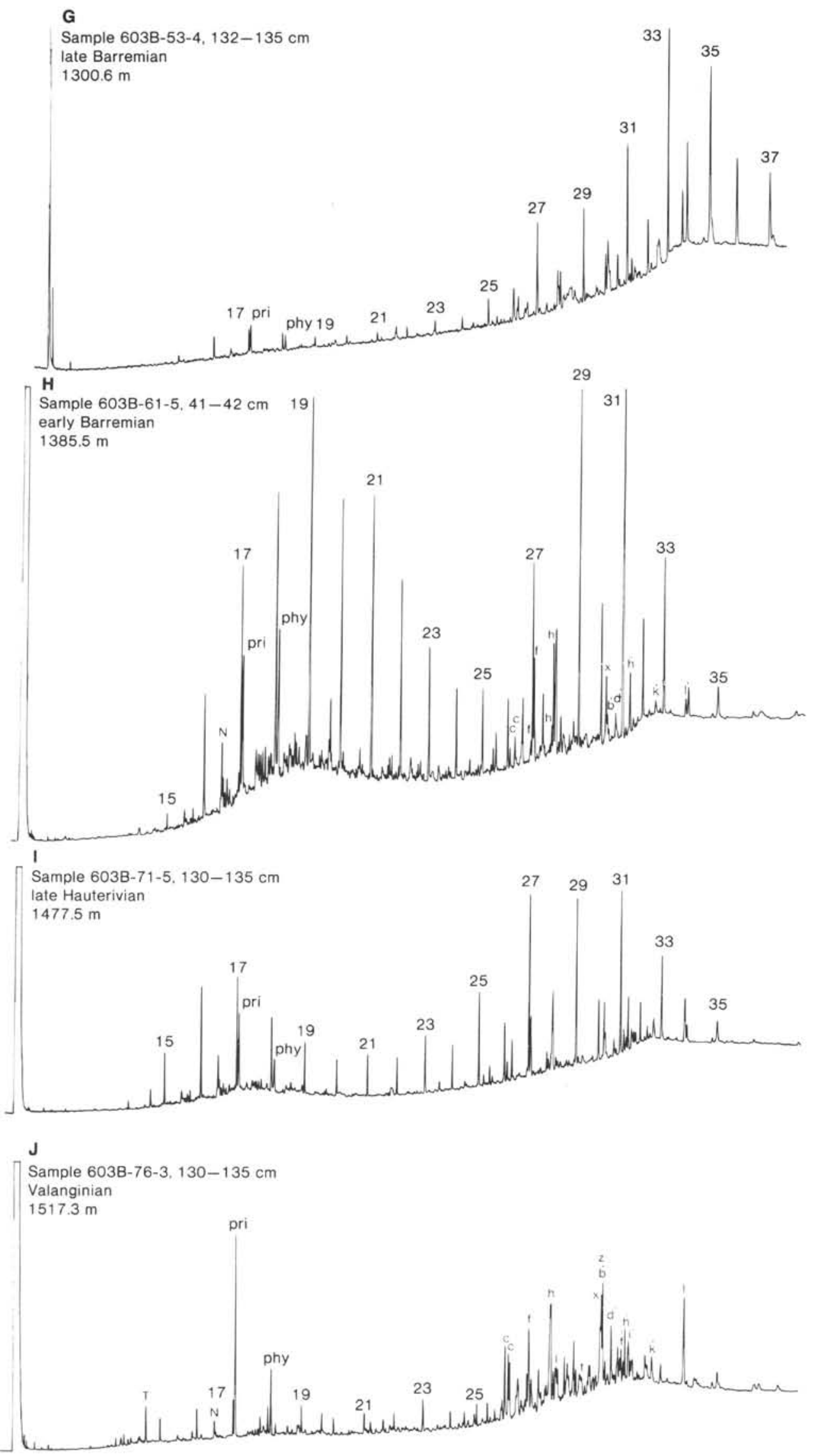

Figure 4 (continued). 
Table 4. Isoprenoid, steroid, and triterpenoid hydrocarbons detected in the nonaromatic hydrocarbon fractions of sediments from DSDP Site 603 (cf. gas chromatograms in Fig. 4).

\begin{tabular}{|c|c|c|}
\hline & Compound & Structure \\
\hline $\mathrm{F}$ & $=$ Farnesane & \\
\hline $\mathrm{T}=$ & $=2,6,10$-trimethyltridecane & \\
\hline $\mathrm{N}=$ & $\begin{array}{l}=\text { Norpristane } \\
=\text { Pristane }\end{array}$ & \\
\hline $\begin{array}{l}\text { pri }= \\
\text { phy }=\end{array}$ & $\begin{array}{l}=\text { Pristane } \\
=\text { Phytane }\end{array}$ & \\
\hline $\mathrm{a}=$ & $=$ Phytadienes & \\
\hline b & $=\mathrm{C}_{27}$ sterene $\left(\mathrm{M}^{+} / \mathrm{BP} 370,355\right)$ & \\
\hline c & $=$ Diacholestene & $\mathrm{I}, \mathrm{R}=\mathrm{H}$ \\
\hline $\begin{array}{l}\text { d } \\
\text { e }\end{array}$ & $\begin{array}{l}=\mathrm{C}_{29} \text { sterene }\left(\mathrm{M}^{+} / \mathrm{BP} 398,383\right) \\
=\text { Diacholestadiene }\end{array}$ & \\
\hline f & $=24$-methyldiacholestene & $\mathrm{I}, \mathrm{R}=\mathrm{CH}_{3}$ \\
\hline $\mathrm{g}$ & $=24$-methyldiacholestadiene & \\
\hline $\mathrm{h}$ & $=24$-ethyldiacholestene & $\mathrm{I}, \mathrm{R}=\mathrm{C}_{2} \mathrm{H}_{5}$ \\
\hline i & $=22,29,30$-trisnorhop-13(18)-ene & II, $\mathbf{R}=\mathrm{H}$ \\
\hline j & $=$ Cholest-4-ene & III, $\mathrm{R}=\mathrm{H}$ \\
\hline $\mathrm{k}$ & $=$ Cholest-2-ene & IV \\
\hline 1 & $=S \alpha(\mathrm{H})$-cholestane & $\mathrm{V}, \mathrm{R}=\mathrm{H}$ \\
\hline $\mathrm{m}$ & $=$ Cholest-5-ene & VI, $\mathrm{R}=\mathrm{H}$ \\
\hline $\mathrm{n}$ & $=\mathrm{C}_{30}$ triterpane? $\left(\mathrm{M}^{+}{ }_{412}\right)$ & \\
\hline o & $=24$-methylcholesta-4,22-diene & VII, $\mathrm{R}=\mathrm{CH}_{3}$ \\
\hline $\mathrm{p}$ & $=24$-methylcholesta-5,22-diene & VIII, $\mathrm{R}=\mathrm{CH}_{3}$ \\
\hline q & $=\mathrm{C}_{30}$ triterpene? $\left(\mathrm{M}^{+} 410, \mathrm{BP} 395,191\right)$ & \\
\hline $\mathrm{r}$ & $=17 \beta(\mathrm{H})$-trisnorhopane & IX, $\mathrm{R}=\mathrm{H}$ \\
\hline 5 & $=24$-methylcholest-4-ene & III, $\mathrm{R}=\mathrm{CH}_{3}$ \\
\hline $\mathrm{t}$ & $=24$-methy- $5 \alpha(\mathrm{H})$-cholestane & $\mathrm{V}, \mathrm{R}=\mathrm{CH}_{3}$ \\
\hline u & $=24-$ methylcholest-5-ene & VI, $\mathrm{R}=\mathrm{CH}_{3}$ \\
\hline $\mathrm{v}$ & $=24$-ethylcholesta-4,22-diene & VII, $\mathrm{R}=\mathrm{C}_{2} \mathrm{H}_{5}$ \\
\hline w & $=$ 24-ethylcholesta-5,22-diene & VIII, $\mathrm{R}=\mathrm{C}_{2} \mathrm{H}_{5}$ \\
\hline$x=$ & $=30$-nor-17 $\alpha(\mathrm{H})$-hopane & $\mathrm{X}, \mathrm{R}=\mathrm{H}$ \\
\hline$y=$ & 24-ethylcholest-4-ene & III, $\mathrm{R}=\mathrm{C}_{2} \mathrm{H}_{5}$ \\
\hline $\mathrm{z}$ & $=24$-ethyl- $5 \alpha(\mathrm{H})$-cholestane & $\mathrm{V}, \mathrm{R}=\mathrm{C}_{2} \mathrm{H}_{5}$ \\
\hline a' & $=24$-ethylcholest-5-ene & VI, $\mathrm{R}=\tilde{\mathrm{C}}_{2} \mathrm{H}_{5}$ \\
\hline b' & $=30$-norhop-17(21)-ene & $\mathrm{XI}, \mathrm{R}=\mathrm{H}$ \\
\hline$c^{\prime}$ & $=30$-norhop-13(18)-ene & $\mathrm{II}, \mathrm{R}=\mathrm{C}_{2} \mathrm{H}_{5}$ \\
\hline d' & $=$ Hop-17(21)-ene & $\mathrm{XI}, \mathrm{R}=\mathrm{CH}_{3}$ \\
\hline e' & $=30$-normoretane & XII \\
\hline $\mathrm{f}^{\prime}$ & $=17 \alpha(\mathrm{H})$-hopane & $\mathrm{X}, \mathrm{R}=\mathrm{CH}_{3}$ \\
\hline g' & $=$ Fern-8-ene & XIII \\
\hline h' & $=$ Hop-13(18)-ene & $\mathrm{II}, \mathrm{R}=\mathrm{CH}\left(\mathrm{CH}_{3}\right)_{2}$ \\
\hline i’ & $=30$-nor-17 $7(\mathrm{H})$-hopane & $\mathrm{IX}, \mathrm{R}=\mathrm{C}_{2} \mathrm{H}_{5}$ \\
\hline j' & $=17 \alpha(\mathrm{H})$-homohopane $(20 \mathrm{R})$ & $\mathrm{X}, \mathrm{R}=\mathrm{C}_{2} \mathrm{H}_{5}$ \\
\hline k' & $=17 \beta(\mathrm{H})$-hopane & $\mathrm{IX}, \mathrm{R}=\mathrm{CH}\left(\mathrm{CH}_{3}\right)_{2}$ \\
\hline 1' & $=17 \beta(\mathrm{H})$-homohopane & $\mathrm{IX}, \mathrm{R}=\mathrm{CH}\left(\mathrm{CH}_{3}\right) \mathrm{C}_{2} \mathrm{H}_{5}$ \\
\hline $\mathrm{m}^{\prime}=$ & $=17 \beta(\mathrm{H})$-bishomohopane & $\mathrm{IX}, \mathrm{R}=\mathrm{CH}\left(\mathrm{CH}_{3}\right) \mathrm{C}_{3} \mathrm{H}_{7}$ \\
\hline $\mathrm{n}^{\prime}=$ & $=17 \beta(\mathrm{H})$-trishomohopane & $\mathrm{IX}, \mathrm{R}=\mathrm{CH}\left(\mathrm{CH}_{3}\right) \mathrm{C}_{4} \mathrm{H}_{9}$ \\
\hline
\end{tabular}

Note: Structural formulas are given in the Appendix. $\mathrm{M}^{+}=$molecular ion, $\mathrm{BP}=$ base peak.

tive to the cyclic hydrocarbons (steroids and triterpenoids) in all four samples. The pristane/phytane ratio is close to unity in each case, but phytane predominates only in Samples 603B-34-1, 77-79 cm (Fig. 4D) and 603B-34-5, 21-23 cm (Fig. 4F). These samples, however, have a low concentration of 2,6,10-trimethyltridecane $\left(\mathrm{C}_{16}\right.$ isoprenoid, $\left.\mathrm{T}\right)$, which is abundant in the other two samples. An unusually high abundance of this isoprenoid was found in a Callovian carbonaceous claystone from DSDP Hole 534 in the Blake-Bahama Basin, which also contained mainly amorphous aquatic organic matter in the form of fecal pellets (Rullkötter and Mulkhopadhyay, 1984). Unsaturated isoprenoid hydrocarbons (phytadienes) are present in the three Cenomanian samples (Figs. 4D-F).

Sterenes and steradienes are the most abundant steroid hydrocarbons in all four samples. They mainly oc- cur as $\Delta^{4}$ - (III; see Appendix for chemical structures) and $\Delta^{5}$-isomer (VI) pairs, but a $\Delta^{2}$-analog (IV) is present at least in the middle Cenomanian sample. Saturated steranes (V) and rearranged diasteroid hydrocarbons (e.g., I) are less important. An unknown $\mathrm{C}_{30}$-triterpene (q) occurs in all four samples and is the most abundant component in the nonaromatic hydrocarbon fractions of Samples 603B-34-1, 77-79 cm and 603B-34-5, 21$23 \mathrm{~cm}$ (Figs. 4D and 4F). An unknown $\mathrm{C}_{30}$-triterpane (n) eluting before the olefin may be the corresponding saturated hydrocarbon. The same unknown triterpene apparently occurs in a Cenomanian black shale of Hole 530A in the Angola Basin (Rullkötter, Mukhopadhyay, and Welte, 1984). Other triterpenoids in the Cenomanian and Coniacian-Turonian sediments are hopanoids with olefins (II, XI) and $17 \beta(\mathrm{H})$-hopanes (IX) dominating.

The similarity of the upper Barremian to upper Hauterivian sediments with respect to organic carbon content and pyrolysis yields (hydrogen index) is not reflected in the nonaromatic hydrocarbon gas chromatograms of three selected samples shown in Figures 4G-I. The $n$ alkane distribution of Sample 603B-53-4, 132-135 cm (Fig. 4G) is closest to what would be expected for a coaly, terrigenous organic matter type, although part of the long-chain $n$-alkanes above $n-\mathrm{C}_{33}$ may not be derived from higher plant wax alkanes but resemble more those in one of the Cenomanian sediments, where they were described as diagenetically formed from coccolithophore constituents. Both the lower Barremian (Fig. 4H) and the upper Hauterivian samples (Fig. 4I) have bimodal $n$-alkane distributions. In the latter, the lower mode around $n-\mathrm{C}_{17}$ may be ascribed to the high proportion of recycled humic organic matter in this sediment, whereas the origin of the $n$-alkanes around $n-\mathrm{C}_{19}$ is less clear in the lower Barremian sediment. Cyclic hydrocarbons in this sample consist of diasterenes and hopanoid hydrocarbons, both in relatively low concentrations. The nonaromatic hydrocarbon concentrations in the extracts of the other Hauterivian to Barremian samples were too low for unambiguous mass spectrometric identification.

Sample 603B-76-3, 130-135 cm (Valanginian) contains little $n$-alkanes in the nonaromatic hydrocarbon fraction, but an extremely complex steroid hydrocarbon mixture (Fig. 4J) that awaits further detailed mass spectrometric deconvolution. This type of hydrocarbon composition is consistent, however, with the dominantly marine organic matter type determined by kerogen microscopy. Unfortunately, the amount of sample material from the Berriasian-Valanginian Section 603B-80-6 was just sufficient for microscopic investigation, and nothing was left for solvent extraction. This would have allowed, on the basis of the biological marker composition, the testing of any relationship between the bitumen-impregnated saprohuminite and the marine organic matter in the Valanginian sediment. It would have answered the question of whether the marine organic matter is the dominant type in the dark laminae of lithologic Unit VB, with the saprohuminite occurring only once and thus being subordinate in importance. 


\section{Maturity}

The organic matter in the DSDP Site 603 sediments, in so far as it is not recycled, is immature. The mean huminite/vitrinite reflectance values increase only slightly from about $0.20 \%$ in the shallowest Tertiary sample studied to about $0.30-0.35 \%$ in the Barremian to Valanginian section (Fig. 5). The Berriasian-Valanginian saprohuminite has a lower reflectance of about $0.25 \%$ due to the strong bitumen impregnation.

The temperatures of maximum Rock-Eval pyrolysis yields (Espitalié et al., 1977) show a trend consistent with the huminite/vitrinite reflectance values (Fig. 5). Within the Tertiary the $T_{\max }$ values increase from about $380^{\circ} \mathrm{C}$ to about $415^{\circ} \mathrm{C}$, whereas in the Cretaceous most $T_{\max }$ values are close to $425^{\circ} \mathrm{C}$. Lower temperatures were measured, as expected, for the highly sapropelic (Cenomanian) and the bitumen-impregnated Berriasian-Valanginian samples.

\section{CONCLUSIONS}

Although the organic carbon content in the middle Miocene to Pleistocene hemipelagic clays and claystones is relatively low $(<0.75 \%)$, the preservation of the mostly terrigenous organic matter is surprisingly good. The proportion of recycled material in the DSDP Site 603

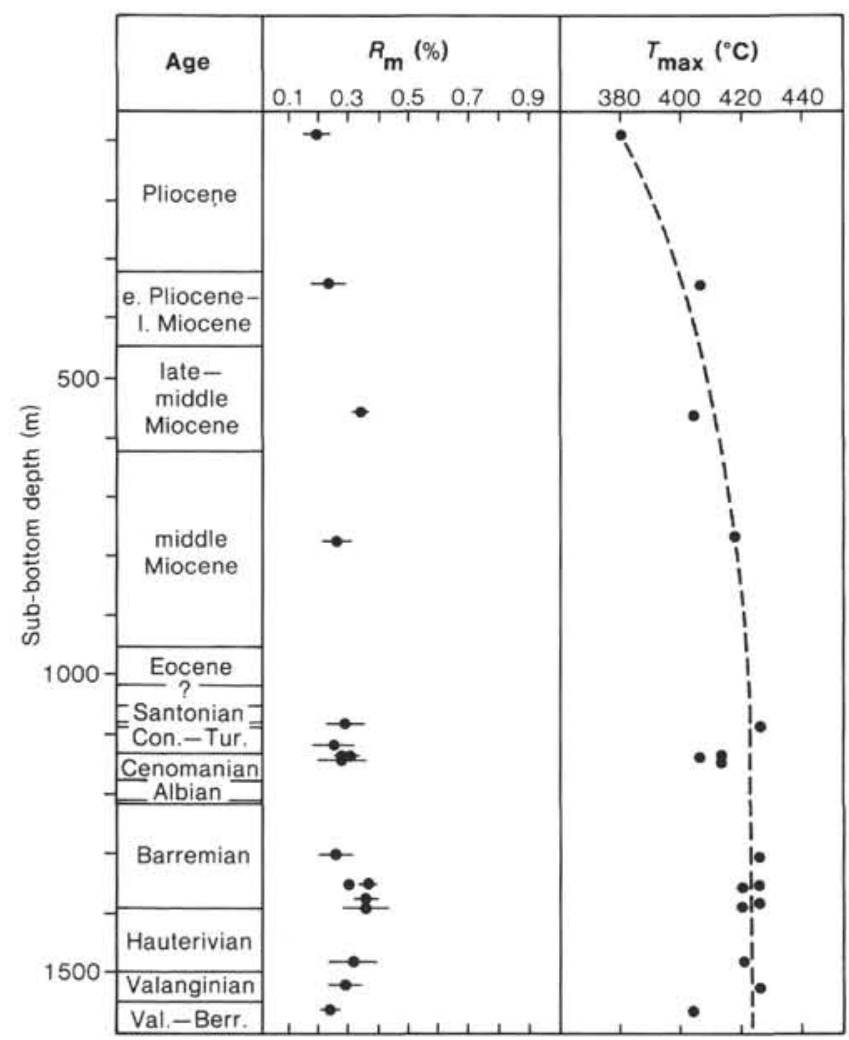

Figure 5. Huminite/vitrinite reflectance $\left(R_{\mathrm{m}}\right)$ and temperature of maximum pyrolysis yield $\left(T_{\mathrm{max}}\right)$ plotted versus depth and stratigraphy for DSDP Site 603 samples. Horizontal bars indicate standard deviations of the vitrinite reflectance measurements. The depth trend indicated for the $T_{\max }$ values is for type III kerogens (terrigenous organic matter). Note: There is a stratigraphically undated interval below the Santonian and a thin Aptian section below the Albian. samples is much lower than in the Blake-Bahama Basin further south (Rullkötter and Mukhopadhyay, unpublished data) or on the Northwest African continental margin (Rullkötter et al., 1982; Rullkötter, Mukhopadhyay, Schaefer, et al., 1984). An intense runoff from a nearby continent which was densely covered with higher plant vegetation and high sedimentation rates at the continental rise will explain the organofacies observed in the Tertiary at Site 603 .

Terrigenous organic matter is most common also in the Cretaceous sediments at the continental rise off Cape Hatteras, as would be expected from previous organofacies surveys along the northwest American continental margin (Tissot et al., 1980; Summerhayes, 1981). Humic and vitrinitic material, mixed with varying amounts of refractory recycled organic matter, was brought down the continental slope into the deep sea, mainly by turbidites. Again, as in the Tertiary, preservation of the organic matter at Site 603 is much better than during the same time period at the more distal Site 534 in the BlakeBahama Basin (Rullkötter and Mukhopadhyay, 1984) where liptinitic organic matter was (microbially) transformed to inert micrinite during transport and deposition in the deep sea. The good preservation (e.g., a piece of humic coal was found associated with interbedded framboidal pyrite in the lower Barremian) is only comprehensible under the assumption of short-distance transport from a coastal swamp to the ultimate place of deposition and rapid burial within the turbidite. Too little reference information is available to estimate more specifically the actual transport distance. If only short-distance transport and not protection within a larger piece of material was the reason for the good preservation of the humic coal/framboidal pyrite association, then we would imagine a very narrow continental shelf, on the order, perhaps, of only a few tens of kilometers, and a steep continental slope.

Two periods in the Valanginian and at the end of the Cenomanian are exceptional in that the sediments contain organic matter that is predominantly of aquatic origin, although it mainly occurs in the form of fecal pellets and is to a large extent structurally degraded. The Valanginian interbedded nannofossil claystones and limestones apparently were deposited before the onset of the turbidite activity at the Valanginian/Hauterivian boundary. The carbonate cycles with parallel laminations indicate autochthonous deposition with alternating conditions for organic matter preservation (oxic/anoxic) caused by periods of intense organic matter production and sedimentation possibly enhanced by restricted (local?) circulation of the bottom water in a relatively narrow North Atlantic Ocean. Since fecal pellets that form the bulk of the organic material in the Valanginian sample studied travel relatively fast through the water column, it is not necessary to postulate that the whole water column was anoxic. It is sufficient that the organic matter supply reduced the oxygen content within the sediment; this is in line with the measured hydrogen index of only about $300 \mathrm{mg} \mathrm{HC} / \mathrm{g} \mathrm{C}_{\text {org }}$, which is lower than typical unaltered, immature, marine organic matter. This indicates partial oxidation of the organic mat- 
ter within the sediment or during settling through the water column, although a partial metabolic hydrogen loss in the material that reached the sediment as fecal pellets is also likely.

The Cenomanian black claystones in Core 603B-34 have a maceral composition similar to the Valanginian sample: structurally degraded marine organic matter in the form of fecal pellets is the dominant constituent. Sharp basal contacts and graded silts at the bases of the black claystones led the Leg 93 shipboard party to suggest that these sediments were emplaced as mud turbidites (Site 603 chapter, this volume). The events continued into the Coniacian-Turonian section and may explain the organofacies similarity of the organic-matter-rich sediments in Cores 603B-32 and -34. In the deeper cores representing lithologic Subunits IVB-D, the black claystones are interbedded with red (oxidized) sediment indicating that at least in an earlier phase of black claystone deposition at the continental rise (by downslope transport) the bottom water was oxic. It is not clear from the data available if anoxic conditions extended into the deeper water toward the Cenomanian/ Turonian boundary, as has been suggested by Graciansky et al. (1984) and Herbin et al. (in press), on the basis of the black shales occurring around the North Atlantic and in neighboring continental areas at this time. There is no doubt that a high marine bioproductivity and subsequent oxygen depletion have led to increased preservation of marine organic matter. From the organic matter composition of the Cenomanian samples from Core 603B-34 and their lithofacies it is not impossible, however, that they were initially deposited on the shelf or upper slope in a restricted oxygen-minimum zone and later redeposited at the continental rise, or that the organic matter even traveled through partly oxygenated water, as explained earlier for the Valanginian sediment.

The organic geochemical investigation of the Cretaceous sediments in particular at DSDP Site 603 revealed the presence of distinctly different organofacies types that also differ from those of synchronous sediments at other Deep Sea Drilling Project locations on the northeast American continental margin or on the opposite side of the North Atlantic Ocean. Where organic matter was preserved in considerable concentrations in the deep sea, the factors responsible are complex, mutually dependent, and often governed by regional or local influences that preclude simple generalizations for the whole North Atlantic Ocean.

\section{ACKNOWLEDGMENTS}

We would like to thank Dr. M. Radke, Dr. P. Müller, and Dr. R. G. Schaefer for extraction/liquid chromatography, Rock-Eval pyrolysis/ organic carbon determination, and gas chromatography, respectively. Technical assistance by W. Benders, U. Disko, Miss A. Fischer, Mrs. B. Kammer, F. J. Keller, F. Leistner, Miss A. Richter, J. Schnitzler, Miss K. Sellinghoff, and H. Willsch is gratefully acknowledged. The manuscript was typed by Mrs. B. Schmitz. Samples were made available by the support of the Deep Sea Drilling Project and the Deutsche Forschungsgemeinschaft (Bonn). Financial support by the Deutsche Forschungsgemeinschaft, Grant No. We $346 / 25$, is gratefully acknowledged. P. K. Mukhopadhyay acknowledges financial support by the Alexander-von-Humboldt-Stiftung, Bonn. The authors are indebted to Dr. Steven Larter (Union Oil Company of California, Brea) and Dr.
John Zumberge (Cities Service Oil Company, Tulsa, Oklahoma) for careful reviews of the manuscript and helpful comments.

\section{REFERENCES}

Benson, W. E., Sheridan, R. E., et al., 1978. Init. Repts. DSDP, 44: Washington (U.S. Govt. Printing Office).

Boyce, R. E., 1972. Carbon and carbonate analyses, Leg 11. In Hollister, C. D., Ewing, J. I., et al., Init. Repts. DSDP, 11: Washington (U.S. Govt. Printing Office), 1059-1071.

Erdman, J. G., and Schorno, K. S., 1978. Geochemistry of carbon: Deep Sea Drilling Project Leg 44. In Benson, W. E., Sheridan, R. E., et al. Init. Repts. DSDP, 44: Washington (U.S. Govt. Printing Office), 605-615.

Espitalié, J., Laporte, J. L., Madec, M., Marquis, F., Leplat, P., Paulet, J., and Boutefeu, A., 1977. Méthode rapide de caractérisation des roches-mères, de leur potentiel pétrolier et de leur degré d'évolution. R. Inst. Fr. Pet., 32:23-42.

Gagosian, R. G., Smith, S. O., and Nigrelli, G. E., 1982. Vertical transport of steroid alcohols and ketones measured in a sediment trap experiment in the equatorial Atlantic Ocean. Geochim. Cosmochim. Acta, 46:1163-1172.

Graciansky, P. C. de, Brosse, E., Deroo, G., Herbin, J.-P., Montadert, L., Müller, C., Sigal, J., and Schaaf, A., 1982. Les formations d'âge Crétacé de l'Atlantique Nord et leur matière organique: Paléogéographie et milieux de dépôt. $R$. Inst. Fr. Pet., 37: 275-336.

Graciansky, P. C. de, Deroo, G., Herbin, J.-P., Montadert, L., Müller, C., Schaaf, A., and Sigal, J., 1984. Ocean-wide stagnation episode in the Late Cretaceous. Nature, 308:346-349.

Herbin, J.-P., and Deroo, G., 1982. Sédimentologie de la matière organique dans les formations du Mésozoique de l'Atlantique Nord. Bull. Soc. Geol. France, 24:497-510.

Herbin, J.-P., Montadert, L., Müller, C., Gomez, R., Thurow, J., and Wiedmann, J., in press. Organic-rich sedimentation at the Cenomanian-Turonian boundary in oceanic and coastal basins in the North Atlantic and Tethys. In Summerhayes, C. P., and Shackleton, N. J. (Eds.), North Atlantic Palaeoceanography: London (Butterworth).

Hollister, C. D., Ewing, J. I., et al., 1972. Init. Repts. DSDP, 11: Washington (U.S. Govt. Printing Office).

Leeuw, J. W. de, von der Meer, F. W., and Rijpstra, W. I. C., 1980. On the occurrence and structural identification of long-chain unsaturated ketones and hydrocarbons in recent and subrecent sediments. In Douglas, A. G., and Maxwell, J. R. (Eds.), Advances in Organic Geochemistry-1979: Oxford (Pergamon Press), pp. 211-217.

McIver, R. D., and Rogers, M. A., 1978. Insoluble organic matter and bitumens in Leg 44 samples. In Benson, W. E., Sheridan, R. E., et al., Init. Repts. DSDP, 44: Washington (U.S. Govt. Printing Office), 645-649.

Mukhopadhyay, P. K., Hagemann, H. W., and Gormly, J. R., 1985. Characterization of kerogens as seen under the aspect of maturation and hydrocarbon generation. Erdöl Kohle Erdgas Petrochem. 38:7-18.

Mukhopadhyay, P. K., Rullkötter, J., Schaefer, R. G., and Welte, D. H., in press. Facies and diagenesis of Nankai Trough Sediments, Deep Sea Drilling Project Leg 87A. In Kagami H., Karig, D. E., et al., Init. Repts. DSDP, 87A: Washington (U.S. Govt. Printing Office).

Ourisson, G., Albrecht, P., and Rohmer, M., 1979. The hopanoids. Paleochemistry and biochemistry of a group of natural products. Pure Appl. Chem., 51:709-729.

Radke, M., Sittardt, H. G., and Welte, D. H., 1978. Removal of soluble organic matter from rock samples with a flowthrough extraction cell. Anal. Chem., 50:663-665.

Radke, M., Willsch, H., and Welte, D. H., 1980. Preparative hydrocarbon group-type determination by automated medium pressure liquid chromatography. Anal. Chem., 52:406-411.

Rullkötter, J., Cornford, C., and Welte, D. H., 1982. Geochemistry and petrography of organic matter in Northwest African continental margin sediments: quantity, provenance, depositional environment and temperature history. In von Rad, U., Hinz, K., Sarnthein, M., and Seibold, E. (Eds.), Geology of the Northwest African Continental Margin: Berlin, Heidelberg, New York (Springer-Verlag), pp. 686-703. 
Rullkötter, J., and Mukhopadhyay, P. K., 1984. Jurassic and mid-Cretaceous carbonaceous claystones in the western (DSDP Leg 76) and the eastern (DSDP Leg 79) North Atlantic. In Schenck, P. A., Lijmbach, G. W. M., and de Leeuw, J. W. (Eds.), Advances in Organic Geochemistry - 1983: Oxford (Pergamon Press), pp. 761-767.

Rullkötter, J., Mukhopadhyay, P. K., Schaefer, R. G., and Welte, D. H., 1984. Geochemistry and petrography of organic matter in sediments from Deep Sea Drilling Project Sites 545 and 547, Mazagan Escarpment. In Hinz, K., Winterer, E. L., et al., Init. Repts. DSDP, 79: Washington (U.S. Govt. Printing Office), 775-806.

Rullkötter, J., Mukhopadhyay, P. K., and Welte, D. H., 1984. Geochemistry and petrography of organic matter in sediments from Hole 530A, Angola Basin, and Hole 532, Walvis Ridge, Deep Sea Drilling Project. In Hay, W. W., Sibuet, J.-C., et al., Init. Repts. DSDP, 75, Pt. 2: Washington (U.S. Govt. Printing Office), 10691087.

Rullkötter, J., von der Dick, H., and Welte, D. H., 1981. Organic petrography and extractable hydrocarbons of sediments from the eastern North Pacific Ocean, Deep Sea Drilling Project Leg 63. In Yeats, R. S., Haq, B. U., et al., Init. Repts. DSDP, 63: Washington (U.S. Govt. Printing Office), 819-836.
Stach, E., Mackowsky, M. T., Teichmüller, M., Taylor, G. H., Chandra, D., and Teichmüller, R., 1982. Coal Petrology: Berlin, Stuttgart (Gebrüder Bornträger).

Staplin, F. L., 1969. Sedimentary organic matter, organic metamorphism and oil and gas occurrence. Bull. Can. Pet. Geol., 17:47-66.

Summerhayes, C. P., 1981. Organic facies of middle Cretaceous black shales in deep North Atlantic. Am. Assoc. Pet. Geol. Bull., 65: 2364-2380.

Tissot, B., Demaison, G., Masson, P., Delteil, J. R., and Combaz, A., 1980. Paleoenvironment and petroleum potential of middle Cretaceous black shales in Atlantic basins. Am. Assoc. Pet. Geol. Bull., 64:2051-2063.

Volkman, J. K., Eglinton, G., Corner, E. D. S., and Sargent, J. R., 1980. Novel unsaturated straight-chain $\mathrm{C}_{37}-\mathrm{C}_{39}$ methyl and ethyl ketones in marine sediments and a coccolithophore Emiliania Huxleyi. In Douglas, A. G., and Maxwell, J. R. (Eds.), Advances in Organic Geochemistry - 1979: Oxford (Pergamon Press), pp. 219227.

Date of Initial Receipt: 6 March 1985

Date of Acceptance: 21 September 1985

APPENDIX

Chemical Structures<smiles>[R]C(CCC(C)C1=C2CCC3C4CCCC[C@]4(C)CCC3[C@@]2(C)CC1)C(C)C</smiles>

I<smiles>[R]C(CCC(C)[C@H]1CC[C@H]2[C@@H]3CC[C@H]4CCCC[C@]4(C)[C@H]3CC[C@]21C)C(C)C</smiles>

V

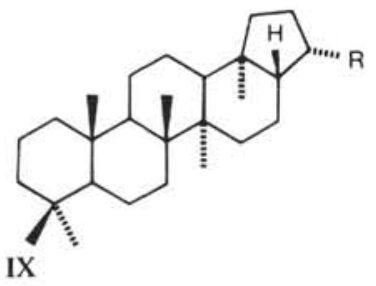

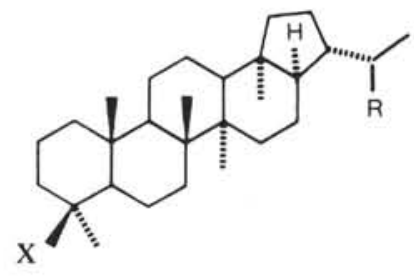<smiles>[R]C(CCC(C)C1CCC2C3CC=C4CCCC[C@]4(C)C3CC[C@]12C)C(C)C</smiles>

VI<smiles>[R]C1CCC2=C3CC[C@@H]4[C@](C)(CC[C@@H]5[C@@](C)(I)CCC[C@@]54C)[C@]3(C)CC[C@@]21C</smiles><smiles>[R]C(CCC(C)[C@H]1CCC2C3CCC4=CCCC[C@]4(C)C3CC[C@]21C)C(C)C</smiles>

III<smiles>[R]C(CCC(C)[C@H]1CC[C@H]2C3CCC4CC=CC[C@]4(C)C3CC[C@@]21C)C(C)C</smiles><smiles>[R]C(/C=C/C(C)[C@H]1CC[C@H]2[C@@H]3CCC4=CCCC[C@]4(C)[C@H]3CC[C@@]21C)C(C)C</smiles>

VII

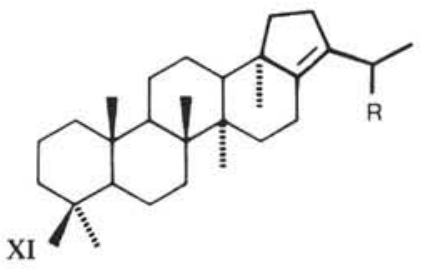<smiles>[R]C(/C=C/C(C)[C@H]1CC[C@H]2[C@@H]3CC=C4CCCC[C@]4(C)[C@H]3CC[C@@]21C)C(C)C</smiles><smiles>[M]#C[C@@]1(C)CCC[C@]2(C)C3=C(CC[C@@H]12)[C@@]1(C)CC[C@]2(CC[C@@H]2C(C)C)[C@@]1(C)CC3</smiles>

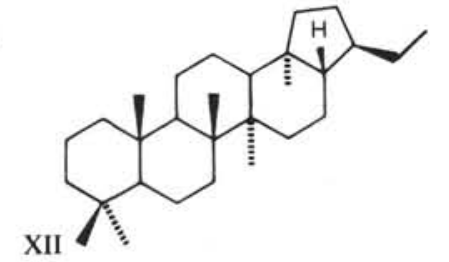

